their families of transfers and admissions to Aberdeen was one of the major challenges for mental health services in Shetland for many years. In the summer of 2015 , we implemented evidence-based approaches for those who suffered from personality disorders. This group of patients had in the past made up a large proportion of hospital admissions to Aberdeen. A very helpful voluntary peer review by experts in personality disorders from the Royal College of Psychiatrists resulted in further improvements in clinical practice. In addition, crisis and home treatment principles were implemented, preventing hospital admissions in many cases. As a result acute, psychiatric admissions to Royal Cornhill Hospital in Aberdeen reduced significantly over the following 2 years (Table 1).

\section{Conclusion}

Practising psychiatry in Shetland is a unique and potentially rewarding experience, both personally and professionally. It provides the opportunity to develop as a generalist in challenging conditions and to lead on service development. Photos of Shetland by the author can be found in the supplementary material.

\section{Supplementary material}

Supplementary material is available online at https://doi.org/10.1192/bji.2018.2.

\section{References}

Ft.com (2018) Why Shetland is one of the UK's Hottest Housing Markets. [online] Available at: https://www.ft.com/content/a63576221542-11e7-b0c1-37e417ee6c76 (accessed 8 February 2018).

Nicholson L. (2008) Rural mental health. Advances in Psychiatric Treatment, 14 (4), 302-11.

Shb.scot.nhs.uk (2018) About NHS Shetland. [online] Available at: http://www.shb.scot.nhs.uk/board/index.asp (accessed 8 February 2018).

Shetland.gov.uk (2018) https://www.shetland.gov.uk/ Health_Social_Care_Integration/default.asp (accessed 8 February 2018).

Shetland.org (2018) Shetland.org I Official Gateway to the Shetland Islands. [online] Available at: http://www.shetland.org (accessed 8 February 2018).
PSYCHIATRY UNDER RESTRICTIVE CONDITIONS

\title{
Correctional psychiatry in Nigeria: dynamics of mental healthcare in the most restrictive alternative
}

\author{
A. O. Ogunlesi ${ }^{1}$ and A. Ogunwale ${ }^{2}$
}

\begin{abstract}
${ }^{1}$ Retired Chief Medical Director/ Chief Consultant Psychiatrist Forensic Unit, Neuropsychiatric Hospital, Aro, Abeokuta, Nigeria; email ogunlesi1952@yahoo.com ${ }^{2}$ Senior Consultant Psychiatrist, Forensic Unit, Neuropsychiatric Hospital, Aro, Abeokuta, Nigeria; email monaolapo@yahoo.co.uk

Conflicts of interest. None.

doi:10.1192/bji.2017.13

(c) The Authors 2018. This is an Open Access article, distributed under the terms of the Creative under the terms of the Creative bution-

NonCommercial-NoDerivatives licence (http://creativecommons. org/licenses/by-nc-nd/4.0/), which permits non-commercial re-use, distribution, and reproduction in any medium, provided the original work is unaltered and is ginal work is unaltered and is properly cited. The written permission of Cambridge University Press must be obtained for commercial re-use or in order to create a derivative work.
\end{abstract}

Nigeria has poorly structured services for correctional mental health driven by a mix of socioeconomic and legal factors. The archaic asylum systems established in the early part of the 20th century under the Lunacy ordinance of 1916 are no longer fit for purpose. The present strategy is to provide mental healthcare for mentally abnormal offenders within some prisons in the country. The current models for this are poorly staffed and underfunded. Adoption of task-shifting approaches based on evidence-based strategies within the context of professional innovation, government commitment and international collaboration should help to develop and sustain the needed correctional psychiatry services.

The history of correctional psychiatry in Nigeria can be traced to the earliest part of the 20th century when two important lines of 'asylums' were established under the Lunacy Ordinance of 1916 by the British colonial administration. The first line involved what could be regarded as 'non-prison' asylums in the southern protectorate, with two asylums being established in Calabar and Yaba by 1907 and a third one following in 1944 in Lantoro (Laws of Nigeria, 1948). These asylums were for the custody of people with mental illness who were not necessarily offenders. In addition to these three, selected native authorities mainly in the northern protectorate of Nigeria (as it was then known) were also empowered by the ordinance to establish asylums. The second line related to prison-based asylums that essentially comprised prison cells designated for the custody of offenders with mental illness (Laws of Nigeria, 1948).

Over time, the non-prison asylums were either neglected or they were mainstreamed into modern day psychiatric hospitals without specific facilities to secure and treat offenders with mental disorders (Ogunlesi et al, 2012). Although the non-prison asylum arrangements are still recognized by law, they are no longer properly funded and their oversight mechanisms ('visiting committees') have become obsolete. Thus, offenders with mental illness are now treated in prisons even when found 'not guilty by reason of insanity' (NGBROI) per section 230 of the Criminal Procedure Act (Laws of the Federation of Nigeria, 2004a). Although this act directs the NGBROI convict to be remanded in an asylum 
Table 1

Models of correctional psychiatry in Nigeria

\begin{tabular}{|c|c|}
\hline Model & Description \\
\hline A & $\begin{array}{l}\text { Mental healthcare is provided by non-psychiatric doctors, nurses and allied staff in the prison clinic. Medication is funded by the prison service or inmate's relatives. } \\
\text { This is the most common model. }\end{array}$ \\
\hline B & $\begin{array}{l}\text { Mental healthcare is provided by a visiting psychiatrist (and a multidisciplinary team where available) from a tertiary health facility within the state the prison is } \\
\text { located. Support services and nursing care are provided by the staff of the prison clinic. Medication is funded by the prison service or occasionally by relatives of the } \\
\text { inmate. This model is far less common than A but is more frequently practised than C. }\end{array}$ \\
\hline C & $\begin{array}{l}\text { Mental healthcare is provided by a visiting psychiatrist (and a multidisciplinary team where available) from a tertiary health facility in which the prison is located. } \\
\text { Nursing care is also provided by a stationed mental health nurse }{ }^{a} \text { from the same tertiary health facility working in partnership with the prison service. Other support } \\
\text { services are provided by the staff of the prison clinic. Medication is funded by the prison service or the inmate's relatives. This is the least practised model in the } \\
\text { country. }\end{array}$ \\
\hline
\end{tabular}

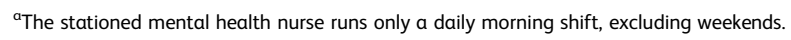

'during the pleasure of the Governor,' it would appear that the only existing interpretation of an asylum in the country is prison.

As noted by international research into the burden of mental disorders in prison settings (Fazel \& Seewald, 2012), current data from local studies also indicate elevated rates of mental disorders among prisoners. In view of the absence of sufficient mental health workers in an overburdened prison system, a treatment gap for mental disorders is likely to exist. This paper describes the structure of the existing correctional psychiatry model and its significant workforce, funding, security and ethical challenges.

\section{Current correctional psychiatry model in Nigeria}

Current prison statistics indicate that there are 68259 prisoners in 240 holding facilities nationwide (Institute for Criminal Policy Research, 2017) and prison authorities are mandated to care for inmates with mental illness by the Prison Act (Laws of the Federation of Nigeria, 2004b). Prisoners in Nigeria thus have a 'right to health' established under this Act as well as under the African Charter on Human and Peoples' Rights (art 16(2)) (Araromi, 2015). It is noteworthy that the Prison Act empowers relevant authorities to transfer prisoners to hospitals when the prison is no longer conducive to the wellbeing of a sick inmate. Based on current experience and practice, there are currently three models of mental healthcare in the Nigerian correctional system and these are summarized in Table 1.

Occasionally, inmates with severe mental disorders that require more intensive assessment and treatment may be transferred to named psychiatric hospitals under some form of hospital-treatment order by the courts (Laws of the Federation of Nigeria, 2004a) or under an administrative order supported by a certificate issued by a prison medical officer (Laws of the Federation of Nigeria, 2004b).

\section{Challenges of correctional psychiatry in Nigeria}

(a) Workforce shortages: There is currently one psychiatrist in the Nigeria prison service and another is in training. There are only a few trained clinical psychologists and psychiatric nurses, with some of them in mainly administrative positions.

(b) Funding for health in prison: All prisons in Nigeria are federal prisons and the funding for health in prison (including mental healthcare) is drawn from budgetary allocations made by the Federal Government through the supervising Ministry of Interior. In many instances, prisons are underfunded and overcrowded. There are significant shortages in the supply of medication for inmates with mental illness as well as in funding for hospital admission when the person can no longer be safely cared for in prison. Often prisoners with severe mental illness are denied their right to health and liberty as they are 'safely' restrained in designated cells to protect them and others from harm instead of being transferred to hospital for adequate treatment.

(c) Security and safety: Prisoners with mental illness face the risk of victimization/harassment by co-inmates and are at risk of suicide, particularly when they are left untreated. In addition, they may pose a risk of violence directed against others. Another critical issue is the safety of mental health staff members who are stationed within prisons during jail breaks.

(d) Ethical challenges:

(i) Privacy and confidentiality: In many prisons, there are no standard interview rooms during clinical interactions with the patient.

(ii) Consent to treatment: One key component of informed consent is that it should be voluntary, as clearly noted in the Nuremberg Code. However, for those who are already incarcerated involuntarily, it would appear that their voluntariness could be environmentally attenuated thereby bringing into question the validity of their consent to treatment or research. 
(iii) Prolonged incarceration of the NGBROI: Because the default mode of criminal law in the country is to remand NGBROI convicts in prison without a definite time frame (i.e. 'during the pleasure of the Governor'), there are ethical challenges with this form of disposal with regard to balancing public safety with respect for individual liberty.

(iv) Equivalence of care: Studies in other regions have shown that equivalence of care does not exist between non-prison and prison populations (Wilson, 2004; Niveau, 2007), and this is clearly evident in prison settings in Nigeria (Araromi, 2015). This amounts to injustice and discrimination. Coupled with this is the disruption of care due to nonavailability of medication, mental health staff and access to a proper location of care.

(v) Context of care: Unfortunately, imprisonment in Nigeria currently tends towards a punitive rather than restorative slant. This has implications on the focus of treatment in prison regarding social recovery and sufficient re-integration of those with mental illnesses upon release.

\section{Future directions for correctional psychiatry in Nigeria}

The current prison environment is not isolated from the mental health treatment gap which is evident in low- and middle-income countries like Nigeria (Wang et al, 2010). To effectively deal with this gap, a community-based approach, where mental health is integrated into primary care, should be adopted at the prison level through the training of prison staff without mental health qualifications. This approach is different from the current models that have not incorporated training. It is to be noted that the training may be based on four or five priority conditions that are recognized mental health issues in the prisons. The training and treatment guidelines should be adapted from the World Health Organization Mental Health Gap Action Programme Intervention Guide (mhGAP-IG), an approach that has been implemented in the country at the primary care level (Adebowale et al, 2014; Gureje et al, 2015).

A contemporary mental health legislation should be enacted to provide proper treatment for prisoners with mental illness as well as for those offenders with mental illness that are under hospital care. The current Lunacy Law (Laws of Nigeria, 1948) does not take the mental health of prisoners into sufficient account, with only a tacit reference under section 17 to the limitation of the powers of a magistrate in granting the discharge of offenders with mental illness detained in asylums under sections 223 and 230 of the Criminal Procedure Act (Laws of the Federation of Nigeria, 2004a). Criminal law provisions such as section 230 of the Criminal Procedure Act need to be amended in such a way as to provide human dignity and the right to liberty, while balancing the individual rights with public safety. Clearly stated parole procedures with reasonable time limits for NGBROI detainees should be critical elements in any substantive amendment to the legislation. These legislative changes will undoubtedly aid in providing the necessary service and funding for correctional psychiatry while also leading to a reduction in the avoidable case load in the various under-resourced correctional mental health services in the country.

\section{Conclusion}

The present context of correctional psychiatry in Nigeria is that of underdevelopment and scarce resources. It is fraught with daunting ethical and practical challenges. Adopting task-shifting approaches based on evidence-based strategies such as the mhGAP-IG within the context of professional innovation, legislative action, government commitment and international collaboration should help to develop and sustain the needed correctional psychiatry services in Nigeria.

\section{References}

Adebowale T., Onofa L. U., Gater R., et al (2014) Evaluation of a mental health training course for primary health care workers in Ogun State, South West, Nigeria. Journal of Psychiatry, 17, 1-5.

Araromi M. A. (2015) Prisoners' rights under the Nigerian law: legal pathways to progressive realization and protection. Afe Babalola University Journal of Sustainable Development Law and Policy, 6 169-197.

Fazel S. \& Seewald K. (2012) Severe mental illness in 33588 prisoners worldwide: systematic review and meta-regression analysis. British Journal of Psychiatry, 200, 364-373.

Gureje O., Abdulmalik J., Kola L., et al (2015) Integrating mental health into primary care in Nigeria: report of a demonstration project using the mental health gap action programme intervention guide. BMC Health Services Research, 15, 242.

Institute for Criminal Policy Research. (2017) World prison brief: Nigeria. Available at http://www.prisonstudies.org/country/nigeria (accessed 20 April 20 2017).

Niveau G. (2007) Relevance and limits of the principle of 'equivalence of care' in prison medicine. Journal of Medical Ethics, 33, 610-613.

Ogunlesi A. O., Ogunwale A., De Wet P., et al (2012) Forensic psychiatry in Africa: prospects and challenges. African Journal of Psychiatry, 15, 3-7.

Wang P. S., Alonso J., Angermeyer M. C., et al (2010) Worldwide use of mental health services for anxiety, mood, and substance disorders: results from 17 countries in the WHO World Mental Health (WMH) Surveys. Lancet, 370, 841-850.

Wilson S. (2004) The principle of equivalence and the future of prison health care. British Journal of Psychiatry, 184, 5-7. 
Cases

Laws of Nigeria (1948) Lunacy Ordinance, Vol. IV, CAP. 121, Government Printer.
Laws of the Federation of Nigeria (2004a) Criminal Procedure Act CAP. C41 Vol. 4, Federal Ministry of Justice.

Laws of the Federation of Nigeria (2004b) Prison Act, CAP. P29, Federal Ministry of Justice.

\title{
SPECIAL \\ Community mental health in rural India: the Shifa project in Padhar Hospital, Madhya Pradesh
}

\author{
Johann A. Ebenezer ${ }^{1}$ and Robert E. Drake ${ }^{2}$
}

${ }^{1}$ Padhar Hospital, Madhya Pradesh, India; email johannebenezer@gmail.com

${ }^{2}$ Dartmouth Medical School, Dartmouth College, Hanover, New Hampshire, USA

Conflict of interest. The authors declare that they have no conflict of interest.

\section{doi:10.1192/bji.2017.8}

(c) The Authors 2018. This is an Open Access article, distributed under the terms of the Creative Commons AttributionNonCommercial-NoDerivatives licence (http://creativecommons. org/licenses/by-nc-nd/4.0/), which permits non-commercial re-use, distribution, and reproduction in any medium, provided the original work is unaltered and is prop work is properly cited. The written permission of Cambridge University Press must be obtained for com mercial re-use or in order to create a derivative work.
People with severe mental disorders in rural India have minimal access to mental health services. Project Shifa entails outreach to patients and families in $\mathbf{7 5}$ villages in rural central India. A team of local health workers led by one psychiatrist provide assessment, medications, education and follow-up services.

In low- and middle-income countries, $76-85 \%$ of people with serious mental disorders do not receive any treatment (WHO, 2013). In India, the median prevalence of mental disorders is 65.4 per 1000 individuals, equivalent to 70 million people across the country (WHO, 2011). Yet India has only 0.3 psychiatrists for every 100000 people (less than 4000 for a population of more than 1 billion), and $75 \%$ of them work in urban areas even though $60 \%$ of the general population is rural (National Institute of Health and Family Welfare, 2010; Kumar, 2011). This paper describes an innovative project to bring community mental healthcare to rural India.

\section{Project description \\ Setting}

Project Shifa provides community mental healthcare in rural central India, serving a population of approximately 35000 people in 75 villages within a radius of about $20 \mathrm{~km}$. The project operates out of Padhar Hospital, a 200-bed, multispecialty, Lutheran mission hospital in the Betul district of the state of Madhya Pradesh. The hospital started a psychiatry department in June 2014, the only full-time mental health service in a radius of $200 \mathrm{~km}$. The department currently consists of only a single psychiatrist. Psychiatry services at the hospital include evaluation and treatment of patients with psychiatric disorders in both outpatient and in-patient settings, as well as consultation services for patients referred from other departments in the hospital. Treatments offered include pharmacotherapy, relevant brief models of psychotherapy and electroconvulsive therapy. Detoxification and de-addiction services are also provided for the considerable number of substance users attending for treatment (particularly for alcohol and nicotine misuse).

Project Shifa is Padhar Hospital's community mental health outreach program, and serves patients with psychiatric disorders and epilepsy in the target area. The team consists of the consultant psychiatrist, an office coordinator, $10 \mathrm{com}$ munity field workers (multipurpose lay health workers employed by the hospital for a variety of outreach activities) and nursing students from the attached college of nursing who are on their psychiatry rotation. All team members are existing employees or students at the hospital, thus avoiding the expense of recruiting an exclusive workforce.

\section{Clinical activities}

The 75 villages covered by the project are divided into 11 clusters of approximately seven villages. The team visits one cluster area each week; it takes approximately 3 months to complete an entire round. The outreach visits are planned at one or more centralised locations in the cluster. During visits, the psychiatrist evaluates new patients screened by the field workers (lay healthcare workers trained at the hospital); patients with severe mental disorders and epilepsy receive free medications; and families receive education about management strategies, the need for compliance and supervision, and emergency contacts. The psychiatrist reviews all patients receiving medications in the field during these visits. During the intervening 3 months between visits, a field worker follows up with patients at their homes twice a month. The team also conducts home visits for patients who cannot travel. Patients with common mental disorders, including alcohol and other substance misuse, are referred to outpatient psychiatry at Padhar Hospital.

Group psychoeducational sessions are held in one cluster each month in rotation, primarily targeting patients with severe mental disorders and epilepsy along with their family members. These sessions focus on educating families about the nature of the disorders and management issues, 